\title{
Ovarian follicular dynamics in Suffolk ewes at different periods of the year
}

\author{
B. Noel, J. L. Bister and R. Paquay \\ Laboratoire de Physiologie Animale, Facultés Universitaires N-D de la Paix, Rue de Bruxelles 61, 5000 \\ Namur, Belgium
}

\begin{abstract}
Five Suffolk ewes underwent daily laparoscopy for 18 days at the onset, middle and end of the breeding season (August, November and February, respectively) and during anoestrus (May) to examine their ovaries. Ovarian follicles $\geq 2 \mathrm{~mm}$ were measured and their relative locations reported on an ovarian map to follow the sequential development of each individual follicle. Some aspects of follicular growth (mean day of emergence and mean number of smail, medium-sized and large follicles, maximum size before regression and ovulation rate) were also studied and compared. Three waves of follicular growth and atresia were observed during the oestrous cycle; two waves occurred during the luteal phase and one during the follicular phase. This cyclic pattern of growth and atresia was not influenced by the stage of the breeding season. A similar turnover of follicles occurred during anoestrus. Features of follicular growth were similar at all stages studied except for the size of the large follicles which were smaller during the two waves of the luteal phase $(P<0.05)$. The number of growing follicles did not vary and the mean ovulation rate was $1.2 \pm 0.4$ at all stages of the breeding season.
\end{abstract}

\section{Introduction}

In most breeds of sheep, only one or two follicles ovulate at the end of each oestrous cycle. Two processes lead to the development of the normal species-specific number of ovulatory follicles (diZerega and Hodgen, 1981; Driancourt et al., 1984; Fortune et al., 1991). First, during follicular recruitment, small antral follicles develop from a pool. Second, during follicular selection, one or more of the recruited follicle(s) are selected to continue(s) maturation, ultimately being ovulated or becoming atretic (diZerega and Hodgen, 1981; Driancourt et al., 1984).

Information about the final stages of follicular growth comes from observations on the follicular phase of the oestrous cycle. It is not known whether the processes of follicular growth that seem to be typical of the follicular phase also occur during the luteal phase and throughout the anoestrous season.

The pattern of follicular development during an entire oestrous cycle has been described in several species of small mammal (for example rodents, see review by Richards, 1980), but it has been more difficult to follow the dynamics of follicular growth and regression in large domestic animals such as cattle or sheep (Fortune et al., 1991).

Some researchers have suggested that follicular growth is continuous and independent of the stage of the cycle (Turnbull et al., 1977; Peters and McNatty, 1980; Lahlou-Kassi and Mariana, 1984; Yenikoye et al., 1989), whereas others have proposed that follicular development in cows (Savio et al., 1988; Sirois and Fortune, 1988; Ginther et al., 1989a, b; Fortune et al., 1991) and ewes (Smeaton and Robertson, 1971; Brand and de Jong, 1973; Jacques, 1989) occurs in waves. There is no agreement on when, during the oestrous cycle, the pattern of waves

Revised manuscript received 17 May 1993. of follicular growth occurs. Brand and de Jong (1973) reported that follicular growth is biphasic in ewes, although Smeaton and Robertson (1971) and Jacques (1989) found three waves.

Most of the studies cited above involved the measurement, counting and histological evaluation of ovaries of animals killed at various times during the oestrous cycle or marking of follicles with India ink followed by several laparoscopies. These techniques have generated much useful information on the development and regression of follicles, but they do not allow the dynamics of the process to be evaluated fully during a complete oestrous cycle. The purpose of the present study was to use repeated laparoscopy to follow the development of individual follicles during an entire oestrous cycle in Suffolk ewes at different periods of the breeding season and at anoestrus.

\section{Materials and Methods}

\section{Animals}

Five sexually mature Suffolk ewes (4-6 years old), clinically normal and with regular oestrous cycles, were used from November 1989 to September 1990. Animals were maintained indoors under natural daylength and were provided with a diet adequate for maintenance.

\section{Experimental procedure}

A preliminary study showed that the breeding season of the ewes begins in early August and ends in March. The dynamics of follicular growth at various periods of the breeding season and in anoestrus were compared by subjecting animals to repeated laparoscopy in November 1989 (breeding season), 


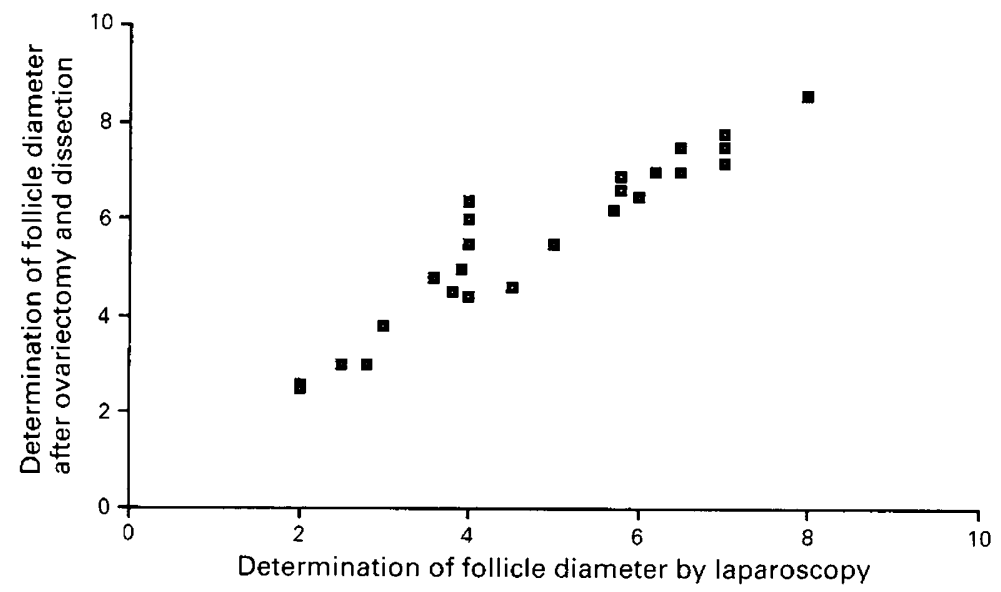

Fig. 1. The correlation between follicular diameters as determined after laparoscopy or after ovariectomy and dissection.

February 1990 (end of breeding season), May 1990 (anoestrus) and August 1990 (onset of the breeding season).

Ovarian follicular dynamics were monitored by non-traumatic laparoscopy (Richard Wolf endoscope with $5 \mathrm{~mm}$ optic fibre and manipulation probe). Local anaesthetic ( $1 \mathrm{ml}$ of $2 \%$ xylocaine) was injected s.c. $3-4 \mathrm{~cm}$ anterior to the udder, $4-5 \mathrm{~cm}$ on each side of the midcentral line. The endoscope and manipulation probe were inserted into the peritoneal cavity at the sites of anaesthetic injections. The observations were performed daily for 17 days. No chemical methods were used to synchronize the animals during the procedure.

The size and diameter of each follicle (diameter $\geq 2 \mathrm{~mm}$ ) were reported on ovarian maps to analyse the pattern of growth and atresia at the ovarian surface. A preliminary study showed that this method for examining the ovaries by laparoscopy correctly measured all follicles. Ovaries from nine ewes were observed by laparoscopy and the diameters of 26 follicles from 2 to $6 \mathrm{~mm}$ were determined. The diameters of the same follicles were then measured following dissection from the ovaries (Fig. 1). The Spearman coefficient of correlation was $0.84(P<0.01, n=26)$. Laparoscope examination of the ovaries allows only those follicles visible on the surface to be monitored. However, $90 \%$ of the total number of ovarian follicles $\geq 2 \mathrm{~mm}$ in diameter can be viewed by laparoscopy, so the results obtained by laparoscopy are representative of the ovarian follicular population.

Daily blood samples were taken before laparoscopy to measure progesterone to distinguish between the follicular and luteal phase of the oestrous cycle. The progesterone concentrations were evaluated by double-antibody radioimmunoassay as described by Bister and Paquay (1983). Progesterone was extracted in samples with hexane (Merck. art. 4367, recovery rate $90-100 \%$ ) before radioimmunoassay. The intra- and interassay coefficients of variation were 3.75 and $8.50 \%$, respectively. The sensitivity of the assay was $40 \mathrm{pg} \mathrm{ml}^{-1}$.

\section{Presentation of results}

Follicles were ranked into three size classes: small follicles, diameter 2-3.5 mm; medium-sized follicles, diameter $4-5.5 \mathrm{~mm}$ and large follicles, diameter $\geq 6 \mathrm{~mm}$.
The day of ovulation was designated as day 0 . The diameters of individual follicles were plotted and inspected for wave patterns. The consecutive waves were designated waves 1,2 and 3 beginning on day 0 . Wave 3 was the ovulatory wave in the cyclic ewes.

The main features of follicular growth calculated were: mean number of small, medium-sized and large follicles, maximal size attained by the largest follicles before regression and ovulation rate.

\section{Statistical analysis}

The data are expressed as means \pm SEM. A three-way analysis of variance was used for comparison between means for the following endpoints: mean day of emergence and mean number of small, medium-sized and large follicles; maximum diameter of largest follicles. The criteria of classification were the period of the year, the waves and the ewes and the model used was: period $x$ wave $x$ ewe (period), period $\times$ wave, wave $x$ ewe. When a significant difference was found, Duncan's multiple range test was used to determine which means were significantly different. Significant differences were set at $P<0.05$.

\section{Results}

The daily records of follicular diameters were used to plot the individual patterns of follicular development and to characterize different features of terminal follicular growth.

During the breeding season (August, November and February), follicular turnover was characterized by the presence of waves of follicular growth beginning at three different times during the oestrous cycle with two waves (wave $I$ and 2) evident during the luteal phase (period characterized by the development and the activity of the corpus luteum and high plasma progesterone concentrations) and one (wave 3) during the follicular phase (period characterized by the luteal regression and low plasma progesterone concentrations) (Fig. 2); each wave lasted approximately 6 days. All follicles of the two luteal phases became atretic and one or two follicles of the follicular 

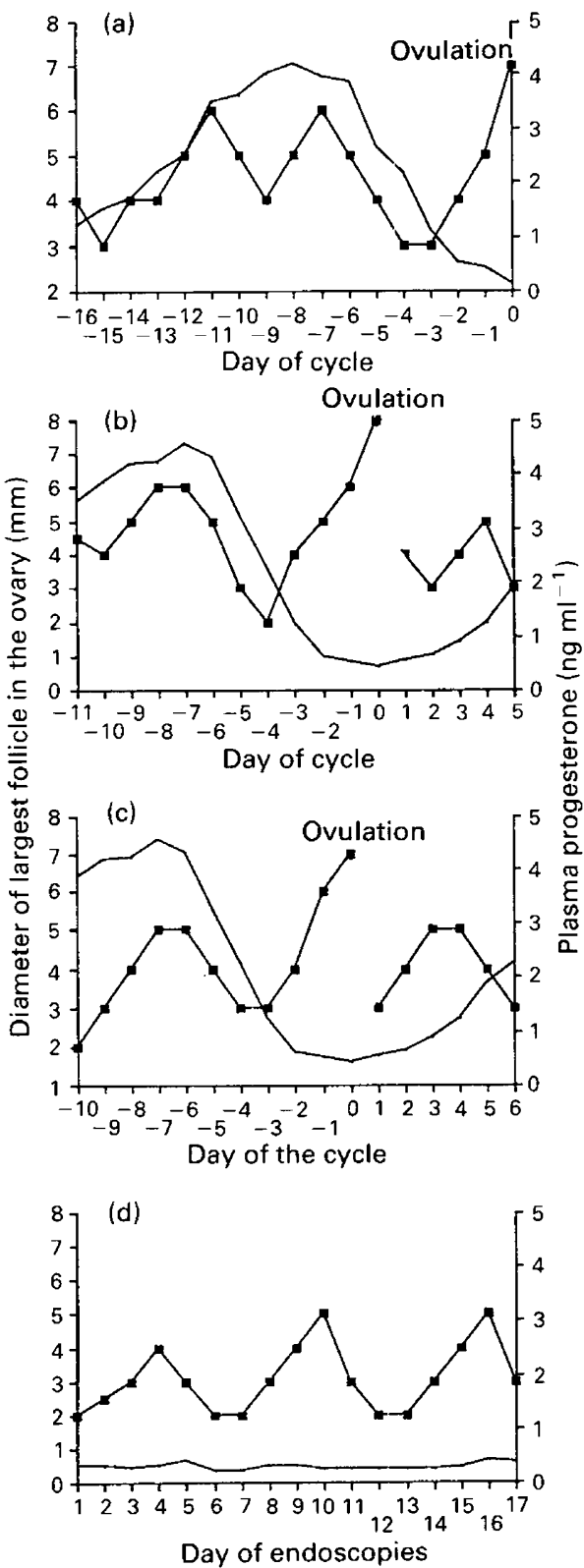

Fig. 2. The pattern of development and regression of the largest follicle ( $\square$ ) present in the ovary of a ewe (a) at the beginning of the breeding season (August), (b) during the breeding season (November), (c) at the end of the breeding season (February) and (d) during anoestrus (May). Changes in the concentration of plasma progesterone are shown by the continuous line.

phase were destined to ovulate. All five ewes had three waves of follicular development per oestrous cycle.

Waves of folliculogenesis were also observed during anoestrus (May) with a 6 day period. The dominant follicles reached a similar size to that found in the follicular phase of the oestrous cycle but then became atretic.

An analysis of the dynamics of follicular growth in the five ewes at the beginning, middle and end of the breeding season showed a trimodal distribution of small, medium-sized and large follicles (Fig. 3). The mean days of emergence of the first,
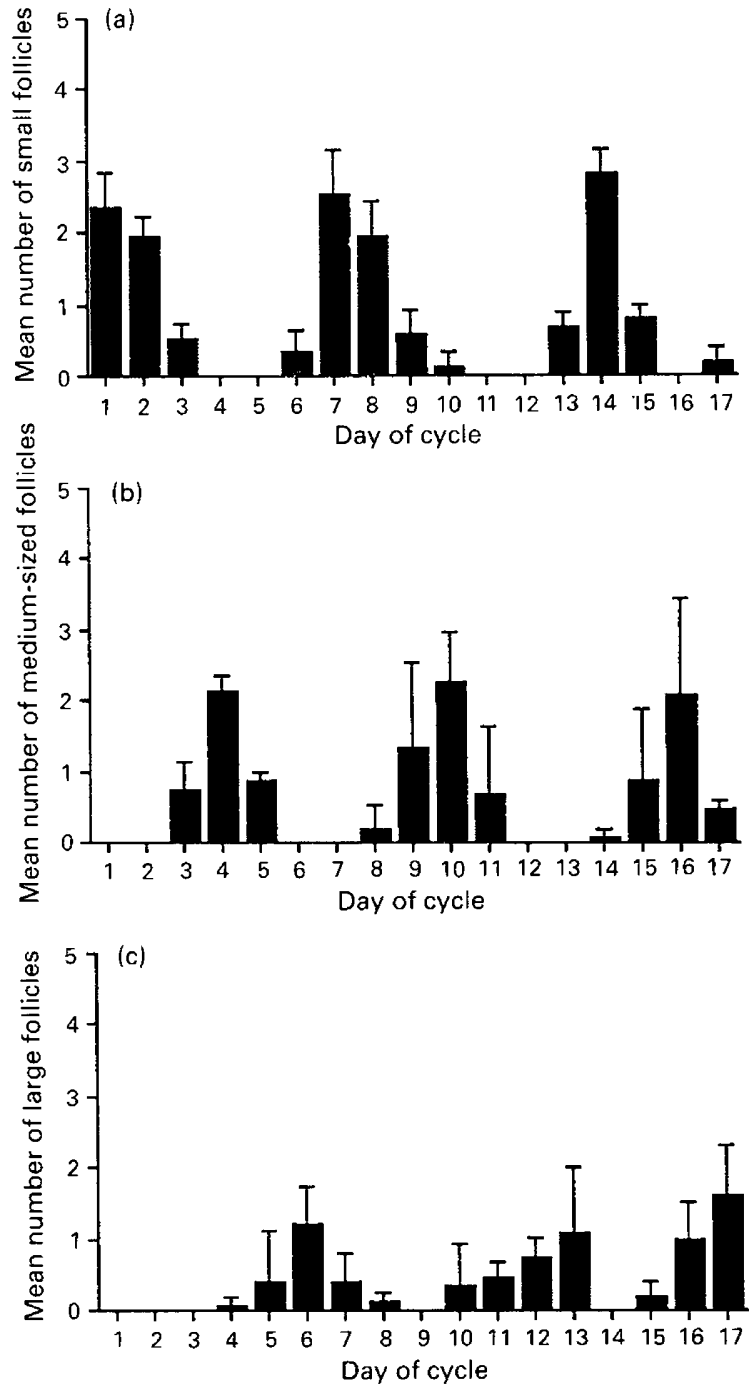

Fig. 3. Mean frequency distribution of (a) small follicles, (b) mediumsized follicles and (c) large follicles in the ovary during the oestrous cycle in five Suffolk ewes. Data were collected at the beginning, in the middle and at the end of the breeding season and were combined. Ovulation occurred on day 17 of the cycle.

second and third waves were $1.6 \pm 0.7,7.6 \pm 0.8$ and $14.0 \pm 0.6$, respectively. The medium-sized follicles appeared on days $4.0 \pm 0.7,9.8 \pm 0.8$ and $15.8 \pm 0.7$ and the large follicles on days $5.9 \pm 1.0,12.0 \pm 1.1$ and $16.5 \pm 0.6$, respectively. The pattern of growth and regression was the same for the three successive waves of follicular development during the oestrous cycle.

Different features of terminal follicular growth were also characterized for the three periods of the breeding season (Table 1). The mean number of small, medium-sized and large growing follicles did not vary significantly between waves. The total number of small, medium-sized and large growing follicles were not significantly different between August, November and February. Ovulation rate was $1.2 \pm 0.4$ for the three stages of the breeding season, which was approximately $2-2.5$ fold lower than the number of large growing follicles. 
Table 1. Main features (means \pm SEM) of the follicular growth for the three periods of the breeding season

\begin{tabular}{|c|c|c|c|c|c|c|c|c|c|}
\hline \multirow[b]{2}{*}{ Characteristic } & \multicolumn{3}{|c|}{ August } & \multicolumn{3}{|c|}{ November } & \multicolumn{3}{|c|}{ February } \\
\hline & Wave I & Wave II & Wave III & Wave I & Wave II & Wave III & Wave I & Wave II & Wave III \\
\hline $\begin{array}{l}\text { Number of small growing } \\
\text { follicles } \\
\text { Number of medium-sized }\end{array}$ & $6.4 \pm 2.1$ & $8.0 \pm 1.8$ & $5.0 \pm 0.8$ & $4.8 \pm 0.4$ & $6.0 \pm 1.6$ & $4.8 \pm 1.1$ & $5.0 \pm 1.0$ & $4.2 \pm 1.1$ & $4.2 \pm 0.4$ \\
\hline $\begin{array}{l}\text { growing follicles } \\
\text { Number of large growing }\end{array}$ & $4.8 \pm 1.6$ & $6.2 \pm 1.7$ & $4.0 \pm 1.3$ & $3.8 \pm 1.8$ & $4.8 \pm 1.1$ & $3.8 \pm 0.4$ & $4.0 \pm 0.8$ & $3.4 \pm 1.7$ & $3.2 \pm 1.3$ \\
\hline $\begin{array}{l}\text { follicles } \\
\text { Maximum size before }\end{array}$ & $2.8 \pm 1.3$ & $3.2 \pm 1.5$ & $3.0 \pm 0.6$ & $2.4 \pm 1.1$ & $3.2 \pm 1.9$ & $3.0 \pm 1.4$ & $2.2 \pm 0.8$ & $2.0 \pm 1.0$ & $2.6 \pm 1.1$ \\
\hline $\begin{array}{l}\text { regression }(\mathrm{mm}) \\
\text { Ovulation rate }\end{array}$ & $5.1 \pm 0.5$ & $5.5 \pm 0.5$ & $\begin{array}{l}5.8 \pm 0.5 \\
1.2 \pm 0.4\end{array}$ & $4.8 \pm 0.6$ & $5.6 \pm 0.6$ & $\begin{array}{l}5.9 \pm 0.8 \\
1.2 \pm 0.4\end{array}$ & $5.1 \pm 0.3$ & $5.5 \pm 0.5$ & $\begin{array}{l}6.3 \pm 0.9 \\
1.2 \pm 0.4\end{array}$ \\
\hline
\end{tabular}

The mean maximum size reached by the largest follicles in the third wave was significantly greater $(P<0.05)$ than that in the first and second waves and this did not change during the breeding season.

\section{Discussion}

To our knowledge, this is the first complete description of ovarian follicular dynamics at different stages of the breeding season and during anoestrus in ewes involving an analysis of development and regression of individual follicles as observed by laparoscopy.

Our results show that in Suffolk ewes the growth of antral ovarian follicles $\geq 2 \mathrm{~mm}$ (also called terminal follicular growth) occurs in three waves. During each wave, follicles $\geq 2 \mathrm{~mm}$ develop from a pool, and a few of them continued maturation and growth. These follicles either ovulate (dominant ovulatory follicle) or become atretic (dominant non-ovulatory follicle). All the largest follicles of the luteal phase become atretic. These observations are consistent with the findings in sheep (Smeaton and Robertson, 1971) and cattle (Ireland and Roche, 1987). Other recent studies using ultrasonographic examination have revealed two (Knopf et al., 1989) or three (Savio et al., 1988; Sirois and Fortune, 1988) waves of development of large follicles in the ovary of heifers during an oestrous cycle. Our results do not support the concept that the turnover of ovarian follicles is continuous and independent of the phase of the cycle (Turnbull et al., 1977; Peters and McNatty, 1980; Lahlou-Kassi and Mariana, 1984; Yenikoye et al., 1989).

The size classes used for ranking the follicles corresponded to main features of follicular growth. Studies of the growth of follicles labelled with India ink showed that follicles reaching ovulation were recruited from those of any size $>2 \mathrm{~mm}$ at the time of natural (Driancourt et al., 1984) or induced (Driancourt and Cahill, 1984) luteolysis. The destruction of follicles of different sizes does not significantly delay ovulation provided some follicles $>2 \mathrm{~mm}$ remain, but ovulation is delayed if all the follicles $>2 \mathrm{~mm}$ are cauterized (Driancourt et al., 1984; Tsonis et al., 1984a). These observations suggest that in sheep, only follicles $\geq 2 \mathrm{~mm}$ in diameter are growing rapidly.

Selection occurs among the pool of recruited follicles. All follicles identified as 'selected' are $>4 \mathrm{~mm}$ in diameter (Fortune et al., 1991). These follicles acquire LH receptors on both the theca and the granulosa layers (Webb and England, 1982) and exhibit maximal responses to FSH in terms of cAMP and oestradiol production (Tsonis et al., 1984b; Henderson et al., 1985; McNatty et al., 1986).

The dominant follicles of a wave are usually the largest and are defined as those that can continue to grow while the others, on both the ipsilateral and contralateral ovaries, undergo atresia (Ireland et al., 1985).

The first, second and third waves of folliculogenesis started, respectively, on days $1-2,7-8$ and 14 of the oestrous cycle. The recruitment of the follicle(s) destined to ovulate took place on day 14 of the cycle which coincides with luteolysis and it is similar to the pattern described in women (Nillson et al., 1982), monkeys (Goodman and Hodgen, 1979) and sheep (Smeaton and Robertson, 1971; Acritopoulou et al., 1977). In contrast, recruitment occurs at the time of the previous ovulation in rats (Hirschfield and Midgley, 1978), and it occurs during the late luteal phase in mares (Driancourt and Palmer, 1984).

During anoestrus, successive waves of folliculogenesis lasting an average of 6 days were observed and the follicles grew to a diameter of $5 \mathrm{~mm}$ or more. It is concluded that the cyclic pattern of follicular growth and atresia seen during the breeding season is also present during the anoestrous period. These observations are in agreement with studies in Texel ewes (Jacques, 1989) and in heifers during early pregnancy (Ginther et al., 1989b). The follicular activity found during the luteal phase and during anoestrus in sheep suggests that rapid follicular growth can occur under a wide range of concentrations of progesterone, oestradiol and FSH and LH pulse frequencies. However, regular 6 day waves of FSH secretion are reported during the oestrous cycle, anoestrus and pregnancy (Bister and Paquay, 1983). There is therefore likely to be a close relationship between waves of folliculogenesis and cycles of FSH.

The mechanisms controlling follicular growth typical of the follicular phase operate in quantitatively the same manner during the luteal phase and during anoestrus. The numbers of small, medium-sized and large follicles were similar for the three waves. Similar observations have been reported in Texel and Ile-de-France ewes (Jacques, 1989) and in heifers (Sirois and Fortune, 1988). However, in prolific breeds of sheep (Romanov, Booroola and Finnish Landrace) high ovulation rates are achieved through a number of different mechanisms involving Downloaded from Bioscientifica.com at 04/26/2023 05:58:15AM 
variations in the number of growing follicles in the follicular phase (Driancourt et al., 1985, 1986).

A large variation in the number of rapidly growing follicles has been reported between animals (Cahill et al., 1979). This partly explains why it is difficult to conclude that there is an effect of the period of the cycle on the follicular population. Turnbull et al. (1977), Lahlou-Kassi and Mariana (1984) and Yenikoye et al. (1989) reached similar conclusions.

Our results suggest that a constant number of small, medium-sized and large follicles develop in waves during the breeding season and the mean ovulation rate is $1.2 \pm 0.4$ at all stages of the breeding season. They do not support the observation of Scaramuzzi and Radford (1983) that the ovulation rate is highest in the late summer and autumn (at the start of the natural breeding season) and declines progressively during the late autumn and winter to reach a minimum just before the ewes become anoestrous.

In the study reported here, the number of large follicles is 2-3 times the ovulation rate. This is in contrast to most of the previous reports which have shown that the number of large follicles is similar to the ovulation rate (Webb et al., 1989; Driancourt et al., 1990).

Our results do not support the concept proposed by Spicer and Carpenter (1979) that growth and replacement of large follicles is more rapid at the end of the oestrous cycle. In fact, the growth rate of the dominant non-ovulatory follicles in the first and second waves did not differ from the growth rate of the dominant ovulatory follicle in the third wave.

Contrary to the previous report by Sirois and Fortune (1988), but consistent with that of Jacques (1989), the maximum size reached by the largest non-ovulatory follicle of the second wave was not smaller than the size of the largest follicle of the first wave. However, the largest non-ovulatory follicles (luteal phase) were smaller than the largest ovulatory follicles and this result might be explained by a negative influence of high concentrations of progesterone during the development of the follicles in the luteal phase.

\section{References}

Acritopoulou S, Haresign W, Foster JP and Lamming GE (1977) Plasma progesterone and $\mathrm{LH}$ concentrations in ewes after injections of an analogue of prostaglandin $\mathrm{F}_{2 a}$ Joumal of Reproduction and Fertility 49 337-340

Bister JL and Paquay R (1983) Fluctuations in the plasma levels of the folliclestimulating-hormone during oestrous cycle, anoestrus, gestation and lactation in the ewe: evidence for an endogenous rhythm of FSH release Theriogenology 25 53-70

Brand A and de Jong WHR (1973) Qualitative and quantitative micromorphological investigations of the tertiary follicle population during the oestrous cycle in sheep Journal of Reproduction and Fertility 33 431-439

Cahill LP, Mariana JC and Mauléon P (1979) Total follicular population in ewes of high and low ovulation rates Joumal of Reproduction and Fertility $\mathbf{5 5}$ 27-36

diZerega GH and Hodgen GD (1981) Folliculogenesis in the primate ovarian cycle Endocrine Reviews 2 27-49

Driancourt MA and Cahill LP (1984) Preovulatory follicular events in sheep Joumal of Reproduction and Ferility 71 205-211

Driancourt MA and Palmer E (1984) Time of ovulation and follicular recruitment in cycling pony mares Theriogenology 21 591-600

Driancourt MA, Gibson WR and Cahill LP (1984) Follicular dynamics throughout the oestrous cycle in sheep. A Review Reproduction Nutrition Developement 25 1-15
Driancourt MA, Cahill LP and Bindon BM (1985) Ovarian follicular populations and preovulatory enlargement in Booroola and control Merino ewes Journal of Reproduction and Fertility 73 93-107

Driancourt MA, Gauld IK, Terqui M and Webb R (1986) Variations in patterns of follicle development in prolific breeds of sheep Joumal of Reproduction and Fertility $\mathbf{7 8} 565-575$

Driancourt MA, Bodin L, Boomarov O, Thimonier J and Elsen JM(1990) Number of mature follicles ovulating after a challenge of human chorionic gonadotropin in different breeds of sheep at different physiological stages journal of Animal Science 68 719-724

Fortune JE, Sirois J, Turzillo AM and Lavoir M (1991) Follicle selection in domestic ruminants Joumal of Reproduction and Fertility Supplement 43 187-198

Ginther OJ, Knopf L and Kastelic JP (1989a) Temporal associations among ovarian events in cattle during oestrous cycles with two and three follicular waves Journal of Reproduction and Fertility 87 223-230

Ginther OJ, Knopf L and Kastelic JP (1989b) Ovarian follicular dynamics in heifers during early pregnancy Biology of Reproduction 41 247-254

Goodman AL and Hodgen GD (1979) Between ovary interaction in the regulation of follicular growth, CL function and gonadotropin secretion in the primate ovarian cycle: I. Follicle cautery and hemicastration in follicular phase Endocrinology 104 1304-1309

Henderson KM, Kieboom LE, McNatty KP, Lun S and Heath D (1985) Gonadotrophin stimulated cyclic AMP production by granulosa cells from Booroola $\times$ Romney ewes with and without a fecundity gene Joumal of Reproduction and Fertility 75 111-120

Hirschfield A and Midgley AR (1978) Morphometric analysis of follicular development in the rat Biology of Reproduction 19 597-605

Ireland JJ and Roche JF (1987) Hypothesis regarding development of dominant follicles during a bovine estrus cycle. In Follicular Growth and Ovulation Rate in Farm Animals pp 1-18 Eds JF Roche and D O'Callagan. Martinus Nijhoff, The Hague

Ireland JJ, Fogwell RL, Oxender WD, Ames K and Cowley JL (1985) Production of estradiol by each ovary during the oestrous cycle of cows Journal of Animal Science 59 764-771

Jacques E (1989) Contrôle de la Croissance Terminale et de la Maturation des Follicules Ovariens de la Brebis pp 46-67 PhD Thesis, Facultés Universitaires Notre-Dame de la Paix, Laboratory of Animal Physiology, Belgium

Knopf L, Kastelic JP, Schallenberger E and Ginther OJ (1989) Ovarian follicular dynamics in heifers: test of two-wave hypothesis by ultrasonically monitoring individual follicles Domestic Animal Endocrinology 6 111-119

Lahlou-Kassi A and Mariana JC (1984) Ovarian follicular growth during the oestrous cycle in two breeds of ewes of different ovulation rate, the D'Man and the Timahdite Journal of Reproduction and Fertility 72 301-310

McNatty KP, Lun S, Heath DA, Ball K, Smith P, Hudson NL, McDiarmind J, Gibb M and Henderson KM (1986) Ovarian activity in Booroola $\times$ Merino ewes which were homozygous, heterozygous and non-carriers of a major gene influencing their ovulation rate Journal of Reproduction and Fertility $\mathbf{7 7}$ 193-205

Nillson L, Wikland M and Hamberger L (1982) Recruitment of an ovulatory follicle in the human following folliclectomy and lutectomy Fertility and Sterility 37 30-34

Peters H and McNatty KP (1980) The Ovary pp 98-106. Granada Publishing London

Richards JS (1980) Maturation of ovarian follicles: actions and interactions of pituitary and ovarian hormones on follicular cell differentiation Physiological Review 60 51-89

Savio JD, Keenan L, Boland MP and Roche JF (1988) Pattern of growth of dominant follicles during the oestrous cycle of heifers Journal of Reproduction and Fertility 83 663-671

Scaramuzzi RJ and Radford HM (1983) Factors regulating ovulation rate in the ewe Journal of Reproduction and Fertility $69353-367$

Sirois J and Fortune JE (1988) Follicular dynamics during the estrous cycle in heifers monitored by real-time ultrasonography Biology of Reproduction 39 308-317

Smeaton TC and Robertson HA (1971) Studies on the growth and atresia of Graafian follicles in the ovary of the sheep Journal of Reproduction and Fertility 25 243-252

Spiecer JC and Carpenter RH (1979) Synchronized breeding of cycling ewes to produce fetuses of known gestation age Laboratory Animal Science $\mathbf{2 9}$ $755-758$

Tsonis CG, Cahill LP, Carson RS and Findlay JK (1984a) Identification at the onset of luteolysis of follicles capable of ovulation in the ewe Journal of Reproduction and Fertility 70 609-614 
Tsonis CG, Carson RS and Findlay JK (1984b) Relationships between aromatase activity, follicular fluid oestradiol-17 $\beta$ and testosterone concentrations, and diameter and atresia of individual ovine follicles Joumal of Reproduction and Fertility 72 153-163

Turnbull KE, Braden AWH and Mattner PE (1977) The pattern of follicular growth and atresia in the ovine ovary Australian Journal of Biological Sciences 30 229-241

Webb R and England BG (1982) Relationship between LH receptor concentrations in thecal and granulosa cells in vivo and in vitro steroid secretion by ovine follicles during the preovulatory period Journal of Reproduction and Fertility 66 169-180

Webb R, Gauld IK and Driancourt MA (1989) Morphological and functional characterization of large antral follicles in three breeds with different ovulation rates Journal of Reproduction and Fertility 87 243-255

Yenikoye A, Mariana JC and Celeux G (1989) Follicular growth during the oestrous cycle in Peul sheep Animal Reproduction Sciences 21 201-211 